\title{
Group Counseling with the Gestalt Technique to Reduce Academic Procrastination
}

\author{
https://doi.org/10.3991/ijet.v15i14.14465 \\ I Ketut Gading $(\bowtie)$ \\ Universitas Pendidikan Ganesha, Bali, Indonesia \\ iketutgading@undiksha.ac.id
}

\begin{abstract}
The objective of this study was to determine the effectiveness of group counseling with the Gestalt approach to diminish academic procrastination behavior in high school students. This research is experimental research with a posttest only control group design. The study population was students in four high schools that were indicated to have high academic procrastination behavior. A total of 61 students who were identified as having high academic procrastination behavior were directly made into sample members. Samples from each school were randomly divided as an experiment group and a control group at each school. Academic procrastination behavior data before and after treatment were analyzed using the Academic Procrastination Behavior Measurement Instrument, while the hypothesis was tested using a t-test. The result shows that group counseling with the Gestalt approach was effective in overcoming the academic procrastination behavior of high school students.
\end{abstract}

Keywords-Group counseling, the Gestalt technique, academic procrastination

\section{Introduction}

Academic procrastination was the behavior of avoiding academic assignments that cause students to experience academic failure, academic unhappiness, and stress [1]. The academic tasks which were usually postponed include administrative tasks such as handing over letters, returning books borrowed at the library, registering exams, and skipping study hours; as well as academic tasks such as doing homework, arranging report, and preparing for the exam [2]. Academic procrastination was done by students in junior high school [3], vocational high school [4], and college [5] which was considered as a form of specific self-regulation failure [6].

Academic procrastination behavior was stimulated by other factors. This problem occurred as a result of modern life filled with temptations, noise, television interference, cellphone interference, peer interference, videogame interference, etc. that allowed students to respond by delaying academic work [7]. The behavior could also occur because of imitating the behavior of others [2], for instance, when a student knew other students did not do academic assignments yet, the student would also do the same thing. It was also concluded that maturity, school term, time schedule, pro- 
crastination intensiveness, self-concept, and self-efficacy impacted academic procrastination [8].

The increase of academic procrastination behavior could not be ignored because it was closely related to academic achievement. This behavior affected assignment and exam scores [9], academic achievement [10], and academic performance [11]. Recent studies also pointed out that procrastination was an obstacle to student performance and academic results [12], as well as life satisfaction [13].

Several studies have been conducted to overcome academic procrastination behavior. Out of several counseling services, research showed that group counseling services were used effectively to overcome academic procrastination combined with other techniques, i.e. a behavioristic approach [14], a reality counseling technique [15], and a self-management technique [16]. However, these techniques required quite a long time in its application because it took time to analyze the causes of academic procrastination. To speed up the process, a technique focusing on the desired results without seeing the cause was needed. Therefore, the Gestalt was arguably an effective technique for this case. This technique was basically a counseling approach performed in a group setting by utilizing group dynamics and aimed to create a context that allowed counselees to fully realize what they were experiencing; and improved the quality of contact they made with others [17]. In this study, the Gestalt technique was performed in group counseling services to overcome academic procrastination behavior in high school students.

\section{Methods}

This research was an experiment study with a Posttest Only Control Group Design (Table 1). The study population was high school students who were indicated to have high academic procrastination behavior. Geographically, those four schools represented North, East, South, and West Bali Island. Those schools also reflected junior and senior high schools, as well as public and private schools.

Table 1. Posttest only control group design (E was the experiment group and $\mathrm{C}$ was the control group).

\begin{tabular}{|l|c|c|c|}
\hline \multicolumn{1}{|c|}{ School } & Group & Treatment & Observation \\
\hline \multirow{2}{*}{ High School 1 } & $\mathrm{E}$ & $\mathrm{X}$ & $\mathrm{O}$ \\
\cline { 2 - 4 } & $\mathrm{C}$ & - & $\mathrm{O}$ \\
\hline \multirow{2}{*}{ High School 2 } & $\mathrm{E}$ & $\mathrm{X}$ & $\mathrm{O}$ \\
\hline \multirow{2}{*}{ High School 3 } & $\mathrm{C}$ & - & $\mathrm{O}$ \\
\hline \multirow{2}{*}{ High School 4 } & $\mathrm{E}$ & $\mathrm{X}$ & $\mathrm{O}$ \\
\cline { 2 - 4 } & $\mathrm{C}$ & - & $\mathrm{O}$ \\
\cline { 2 - 4 } & $\mathrm{E}$ & $\mathrm{X}$ & $\mathrm{O}$ \\
\cline { 2 - 4 } & $\mathrm{C}$ & - & $\mathrm{O}$ \\
\hline
\end{tabular}

To determine students who have high academic procrastination behavior, the Academic Procrastination Behavior Measurement Instrument (APBMI) is used. APBMI consisted of 8 question items. Each item consisted of 8 alternative answers, except 
item 3 and item 6 with 7 alternative answers. The score of each item ranged from 0 to 8 , except for item 3 and item 6, i.e. from 0 to 7 . The ideal minimum APBMI score was 0 while the maximum score was ideally 62 . Students were declared to have high academic procrastination behavior if the APBMI score ranged from 43 to 62. Based on the score, we obtained 61 students who had high academic procrastination behavior in 4 schools. All students who had high academic procrastination behavior were categorized as samples. The sample members at each school were divided into 2 randomly, into the experiment group and the control group (Table 2).

Table 2. Number of student sample members by school.

\begin{tabular}{|c|l|c|c|c|}
\hline No & School & Experiment Group & Control Group & Total \\
\hline 1 & High School 1 & 6 & 5 & 11 \\
\hline 2 & High School 2 & 9 & 9 & 18 \\
\hline 3 & High School 3 & 9 & 9 & 18 \\
\hline 4 & High School 4 & 7 & 7 & 14 \\
\hline \multicolumn{2}{|c|}{ Total } & 31 & 30 & 61 \\
\hline
\end{tabular}

This study involved 2 variables, i.e. group counseling with the Gestalt approach as a treatment variable, and academic procrastination behavior as a criterion variable. Group counseling with the Gestalt approach was an effort to help counselees to prevent and overcome problems that were done in group situations and by utilizing group dynamics. This counseling was carried out with five steps: (1) group formation, (2) transition, (3) discussion, (4) conclusion, and (5) termination. Academic procrastination behavior was measured by questionnaire, and the data obtained in the form of interval data.

The treatment was given simultaneously by 4 trained counselors to organize group counseling with the Gestalt approach. Each school was given treatment by a counselor with the same stages and treatments. There were three things should be noted, i.e. 1) counselors could do interlude activities, such as games, to reduce tension and boredom, and to intense intimacy; 2) if the time was allowable and all group members were ready to attend the following session, further meetings could be held to discuss the next counselee's problem. Otherwise, the discussion of the counselee's problems would take place in the next session; 3 ) the 2nd, 3rd and so on meetings were held with the same stages and activities, with different problems and counselees (Table 3 ).

The academic procrastination behavior data was collected using APBMI compiled by researchers and tested its validity and reliability prior to implementation. The instrument validity test was carried out to test the contents, using a test developed by Gregory [18], and the items, using a part-whole correlation test. The instrument reliability was tested using the Cronbach Alpha test. The content validity test resulted in a content validity coefficient of 1.00 , while the item validity test concluded that all items were valid. Whilst, the reliability test resulted in a Cronbach alpha coefficient of 0.78 . 
Table 3. Five stages of Group Counseling with Gestalt Technique

\begin{tabular}{|c|c|}
\hline Stages & Activities \\
\hline \multirow{4}{*}{ Formation } & $\begin{array}{l}\text { The counselor called group members (experiment group members) to the group counsel- } \\
\text { ing room }\end{array}$ \\
\hline & The counselor accepted the presence of group members friendly and warmly \\
\hline & The counselor explained why they were called to the counseling room \\
\hline & The counselor explained the purpose and stages of the meeting \\
\hline \multirow{2}{*}{ Transition } & $\begin{array}{l}\text { The counselor built commitment thus group members were ready and willing to attend } \\
\text { group counseling to completion } \\
\text { The counselor explained the principles of group counseling to be observed and applied in } \\
\text { following group counseling (the principle of openness and confidentiality) }\end{array}$ \\
\hline & $\begin{array}{l}\text { The counselor built commitment thus group members were ready and willing to attend } \\
\text { group counseling to completion } \\
\text { The counselor explained the principles of group counseling to be observed and applied in } \\
\text { following group counseling (the principle of openness and confidentiality) }\end{array}$ \\
\hline \multirow{6}{*}{ Discussion } & Choosing counselees whose problems would be discussed at the first meeting \\
\hline & $\begin{array}{l}\text { The elected counselee explained the problem, while other group members could ask } \\
\text { questions that caused the counselee's problems to become clearer }\end{array}$ \\
\hline & $\begin{array}{l}\text { The group explored the inaccuracy of the counselee's roles and responsibilities thus the } \\
\text { problem occurred }\end{array}$ \\
\hline & $\begin{array}{l}\text { The group encouraged the counselee to realize the error of their roles and responsibilities } \\
\text { thus the problem occurred with two techniques: } \\
\text { 1. "I am responsible" technique } \\
\text { 2. "Topdog-underdog dialogue" technique }\end{array}$ \\
\hline & $\begin{array}{l}\text { The group encouraged the counselee to improve their roles and responsibilities thus the } \\
\text { problem could be overcome }\end{array}$ \\
\hline & $\begin{array}{l}\text { The group encouraged the counselee to carry out the responsibilities thus the counselee's } \\
\text { problems could be solved }\end{array}$ \\
\hline \multirow[t]{2}{*}{ Conclusion } & $\begin{array}{l}\text { The counselor asked the counselee to convey new understandings, awareness, and re- } \\
\text { sponsibilities obtained through the group counseling }\end{array}$ \\
\hline & The counselor summarized the activities that had been carried out \\
\hline \multirow{3}{*}{ Termination } & The counselor thanked the group members \\
\hline & $\begin{array}{l}\text { Counselors apologized if there were undesirable things happen during counseling that } \\
\text { caused group members unhappy }\end{array}$ \\
\hline & The counselor closed the meeting \\
\hline
\end{tabular}

We analyzed the data in two steps. The first step was prerequisite analysis and the second step was a hypothesis test. The prerequisite analysis was conducted to test the normality of data distribution and homogeneity test of variance. To test the hypothesis, we used a t-test by comparing the average scores of the experiment group and the control group. The first data analysis was performed to test the major hypothesis, and the second analysis was to test the minor hypothesis.

\section{Results and Discussion}

\subsection{Results}

The results show that the average pretest score of the academic procrastination behavior of the experiment group and the control group are relatively similar in the high 
category. Meanwhile, the average posttest score of the academic procrastination behavior of the experiment group is much less than that of the control group (Figure 1) and categorized in the medium and in the high category, respectively. The decreasing score in the experiment group indicates that the treatment using group counseling training with the Gestalt approach is effective to reduce the academic procrastination behavior.

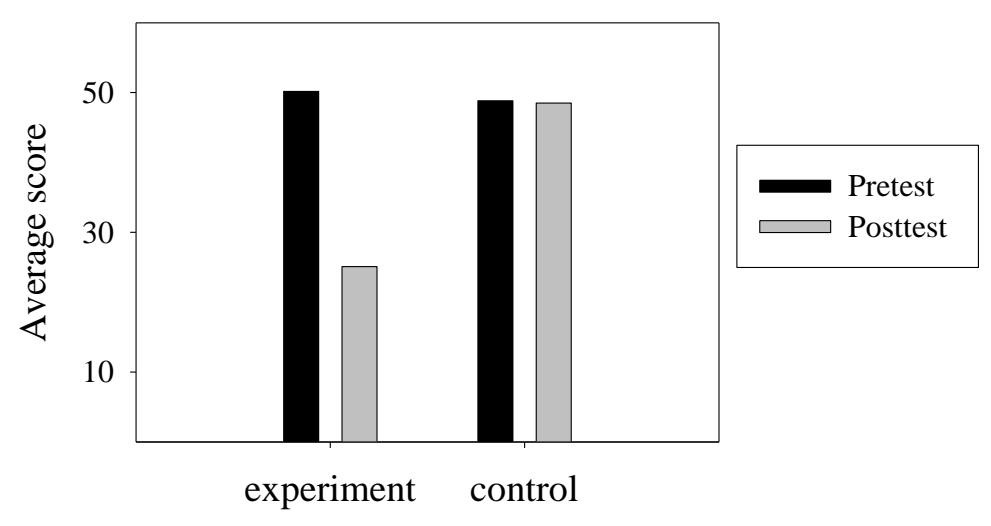

Fig. 1. Average score of academic procrastination in the experiment and control group.

The t-test result shows that there is no difference in the average score of academic procrastination behavior between the experiment group and the control group before the treatment $(\mathrm{t}=0.307$ and $\mathrm{P}=0.760)$. On the contrary, after the treatment, the $\mathrm{t}$-test result shows that there is a significant difference in the average score of academic procrastination behavior between the experiment and control groups $(\mathrm{t}=11.583$ and $\mathrm{P}$ $=0.001)$. The average score of academic procrastination behavior in the experiment group is lower than the average score of the control group. The test proves that group counseling with the Gestalt approach is effective to overcome academic procrastination.

\subsection{Discussion}

The results show that group counseling with the Gestalt approach is effective in overcoming the academic procrastination of high school students. These results are consistent for all study samples, as well as for research samples in each school.

There are two group counseling techniques in the Gestalt approach used in this study, namely the "I am responsible" and the "topdog-underdog dialogue" technique. In the "I am responsible" technique, the counselee is asked to go around to meet his friends in groups and whispering the phrase "I am often late initiating or completing academic assignments and I am responsible for it". Whispering words like that repeat- 
edly and witnessed by his friends is a self-warning of your weakness, as well as a promise to be responsible for overcoming it. When the words are internalized deeply into the system of behavior control (superego), the words will always be present as a reminder. Meanwhile, in the "topdog-underdog dialogue" technique, the counselee imagines dialogue with an important person in his life and is sitting on a chair in front of him (empty chair). In the imaginary dialogue, the counselee does a deep reflection on his behavior that is not good, as well as imagining what is desired or suggested by the important person in his life (topdog) to correct his bad behavior. Imaginary dialogue seems to have better strength than real dialogue because the counselee receives input and suggestions from the important person in his life according to the counselee's perception, not according to an actual person. The input or suggestion according to the counselee's perception has the power to change behavior better than real important person input.

\section{Conclusion}

The group counseling treatment with the Gestalt approach using "I am responsible" and the "topdog-underdog dialogue" technique is applied impressively to decrease the academic procrastination behavior of high school students. The first technique will trigger the superego to avoid that behavior in the future, while the second technique is considered as an advice given by an important person.

\section{$5 \quad$ References}

[1] Abdullah, A., Thalib, M., \& Munifah, M. (2016). Upaya mereduksi perilaku prokrastinasi akademik melalui konseling kelompok dengan teknik self management (studi kasus di kelas XI SMA Negeri 2 Palu). Jurnal Konseling Dan Psikoedukasi, 1(2), 1-14. https://doi.or g/10.25273/counsellia.v5i2.450

[2] Çıkrıkçı, Ö., \& Erzen, E. (2020). Academic Procrastination, School Attachment, and Life Satisfaction: A Mediation Model. Journal of Rational-Emotive \& Cognitive-Behavior Therapy, 38, 225-242. https://doi.org/10.1007/s10942-020-00336-5

[3] Corey, G. (2015). Theory and practice of counseling and psychotherapy. Nelson Education.

[4] Flores, J. G., Gutiérrez, M. R. D. B., \& Umerenkova, A. G. (2020). ?’ Por qué procrastina el alumnado universitario? Análisis de motivos y caracterización del alumnado con diferentes tipos de motivaciones. Revista de Investigación Educativa, 38(1), 183-200. https://doi.org/10.6018/rie.344781

[5] Gading, I. K. (2014). Pengaruh Pelatihan Kendali Diri dan Jenis Kelamin Terhadap Prilaku Prokrastinasi Akademik Siswa SMP. Disertasi. Malang: Pasca Sarjana Universitas Negeri Malang. https://doi.org/10.17977/um001v1i22016p060

[6] Goroshit, M. (2018). Academic procrastination and academic performance: An initial basis for intervention. Journal of Prevention \& Intervention in the Community, 46(2), 131-142. https://doi.org/10.1080/10852352.2016.1198157

[7] Gregory, R. J. (2014). Psychological testing: History, principles, and applications. (7th ed.; A. Dodge, ed.). Harlow: Pearson Education. 
[8] Kandemir, M. (2014). Reasons of academic procrastination: Self-regulation, academic selfefficacy, life satisfaction and demographics variables. Procedia-Social and Behavioral Sciences, 152, 188-193. https://doi.org/10.1016/j.sbspro.2014.09.179

[9] Lakshminarayan, N., Potdar, S., \& Reddy, S. G. (2013). Relationship between procrastination and academic performance among a group of undergraduate dental students in India. Journal of Dental Education, 77(4), 524-528.

[10] Munawaroh, M. L., Alhadi, S., \& Saputra, W. N. E. (2017). Tingkat prokrastinasi akademik siswa sekolah menengah pertama muhammadiyah 9 Yogyakarta. Jurnal Kajian Bimbingan Dan Konseling, 2(1), 26-31. https://doi.org/10.17977/um001v2i12017p026

[11] Nurhasanah, D., \& Ilfiandra, I. (2017). Perbandingan prokrastinasi akademik mahasiswa berdasarkan angkatan. Journal of Innovative Counseling: Theory, Practice, and Research, 1(02), 74-82.

[12] Puswanti. (2014). Upaya Mereduksi Prokrastinasi Akademik Melalui Konseling Kelompok dengan Pendekatan Behavioristik pada Siswa SMK. Psikopedagogia, 3(1), 11-19. https://d oi.org/10.12928/psikopedagogia.v3i1.4461

[13] Riansyah, H., Satrianta, H., \& Astriyaningsih, A. (2018). Bimbingan Kelompok Teknik Role Play Untuk Mereduksi Prokrastinasi Akademik Siswa. Jurnal Fokus Konseling, 4(1), 72-78. https://doi.org/10.26638/jfk.527.2099

[14] Steel, P. (2010). The procrastination equation: How to stop putting things off and start getting stuff done. Random House Canada.

[15] Wahyuni, W. D., \& Muhari, H. (2014). Penerapan Konseling Kelompok Realita untuk Mengurangi Perilaku Prokrastinasi Akademik Siswa Kelas VIII C SMP Negeri 20 Surabaya. Jurnal BK UNESA, 4(3). https://doi.org/10.35326/pencerah.v4i1.288

[16] Yilmaz, M. B. (2017). The Relation between Academic Procrastination of University Students and Their Assignment and Exam Performances: The Situation in Distance and Faceto-Face Learning Environments. Journal of Education and Training Studies, 5(9), 146-157. https://doi.org/10.11114/jets.v5i9.2545

[17] You, J. W. (2015). Examining the effect of academic procrastination on achievement using LMS data in e-learning. Journal of Educational Technology \& Society, 18(3), 64-74.

[18] Zuama, H. S. N. (2015). Gambaran Prokrastinasi Akademik Pada Mahasiswa Angkatan 2007 Yang Sedang Skripsi Di Program Studi Pg Paud. Kreatif, 18(1), 68-77.

\section{Authors}

First Author is an associate professor at the Department of Guidance and Counseling, Universitas Pendidikan Ganesha, Jl. Udayana no. 11, Singaraja, Bali 81116, Indonesia.

Article submitted 2020-05-24. Resubmitted 2020-07-02. Final acceptance 2020-07-03. Final version published as submitted by the author. 